\title{
The Effect of Electronic Taxing System in Creating Taxpayers Insight about the Equity and Justice of Tax System
}

\author{
Mesele Kebede Manaye, B. C. M. Patnaik, Ipseeta Satpathy
}

\begin{abstract}
: is well known, nowadays the government of any state has to collect sufficient revenue as much as possible in order finance its operation. But in reality, government of any state has facing difficulty in collecting revenue from its citizen due to various ins and outs. Among the most important reasons one is lack of tax fairness and justice. The primary objective of this study was to examine the effect of electronic taxation system in creating an insight about the fairness of tax administration system in Wolaita Sodo town. The cross sectional survey method was adopted and self administered survey and in-depth interview has been used to collect the data. The data has been collected from 192 individual business profit tax payers from category " $B$ " tax payers and 20 tax officers for interview through systematic random sampling techniques. The data has been analyzed by correlations and multiple regressions. The findings shows that fairness of taxation system is directly related with tax complexity, tax general knowledge, tax general fairness, exchange fairness, horizontal fairness, vertical fairness, redistributive fairness and administrative fairness and have significant effects on tax fairness in the current tax system but General fairness is insignificant at 5\% level of CI.Finally, based on the findings possible recommendations were given. The tax authorities should provide sufficient tax training to improve the awareness of tax payer's towards taxation system. More efforts would be exerted in providing tax information through various means at local and federal level about the rights and duties of tax payer's to bring the growth in the economy of the country in general and well being of its citizens in particular. Thereby, enhancing fair tax collection and providing basis for further research in a broader scope.
\end{abstract}

Keywords: Tax Taxpayers' insight, Fairness, Wolaita zone, Ethiopia

\section{INTRODUCTION}

For last long time many countries whether they are civilized or uncivilized, they used tax as a one means of managing national income. The word 'tax' can be defined as an obligatory imposition charged by the government of the state on income, expenditure, assets and capital of its citizens and for this nothing else which is equivalent is expected by the citizens.

Revised Manuscript Received on December 30, 2019.

* Correspondence Author

Mesele Kebede Manaye, Research Scholar, School of Management, Kalinga Institute of Industrial Technology, Bhubaneswar, India.

E-mail:mesiyek2002@yahoo.com

Dr. B. C. M. Patnaik, Professor, School of Management, Kalinga Institute of Industrial Technology, Bhubaneswar, India.

E-mail: B.C.M.Patnaik

Dr. Ipseeta Satpathy, Senior Professor, School of Management, Kalinga Institute of Industrial Technology, Bhubaneswar, India. E-mail: ipseeta@ksom.ac.in

(C) The Authors. Published by Blue Eyes Intelligence Engineering and Sciences Publication (BEIESP). This is an open access article under the CC BY-NC-ND license (http://creativecommons.org/licenses/by-nc-nd/4.0/)
The tax administration system should be based on certain fundamental rules like certainty, equity and fairness, convenience and efficiency to administer the tax system and to collect sufficient revenue (Adam Smith, 1776). Taxation and government spending on valuable projects indicates the promissory obligation of tax payers and the government because tax payer's pays their taxes when they are satisfied with the goods and services provided by the government (Moore 2004). It impossible to conclude that, the greater efficiency and effectiveness of tax authorities was the only means of achieving the voluntary compliance of tax payers. Various researchers concluded that absence of taxpaying culture was the main factor which hinders the long lasting revenue base. If the tax payers perceive that there is partial treatment, miss-appropriation of the collected revenue, discrimination and fraud, the voluntary compliance of tax payers was adversely affected. According to Brook, 2001; Devos, 2008; Kirchler, 2007, Tax payer's voluntary compliance with taxation can be affected by various factors; among them the most common were psychological, social and Economical. According to Bhatia, (1976) in order to ensure fairness and equity in tax system, the most important principles that should be satisfied by any taxation system were equity or fairness and certainty. Tax payer's compliance can also affected by their attitude towards fairness and equity of the taxation system. (Jackson \&Milliron, 1986). In other words, they will not tend to pay taxes if they perceive that the taxation system was unfair. Tax payers tend to not comply with the tax system and hide their true income, when they perceived they are treated unfairly by the tax system. (Etzioni, 1986). The tendency of tax payer's non-compliance increases, when they thought the tax administration system was unfair and inefficient. Bradley(1994). This was also confirmed by Due and Friedlaender (1981), when the existing tax system was not fair and equitable and also partial treatment of tax payer's they will not report their correct and true affairs. Tax payer's voluntary compliance was also affected by peer and referent groups like relatives and friends who are engaged in similar business. In addition to this the efficiency and effectiveness of tax authorities plays an important role in ensuring tax payer's voluntary compliance.(Palil,2010) According to Palil \& Mustapha, 2011, if tax payers perceive that the government utilizes the revenue collected on productive projects, the voluntary compliance of tax payer's enriched. But they perceived that there is miss-utilization of the public funds on unnecessary activities, they are trying to hide their true income and escape from paying taxes. This was also confirmed by, Fjeldstad\& Ranker, 2003,

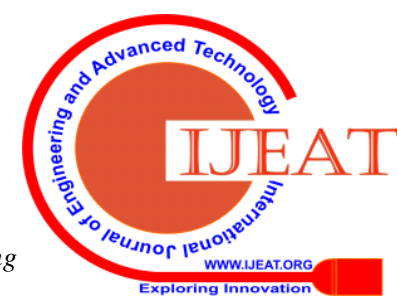


The efficiency and effectiveness of the government in wisely spending the public funds to produce public goods and services was significantly associated with tax payer's voluntary compliance towards taxation.

Fjeldstad and Ranker (2003). Regarding Ethiopia, the existing government system has been developed from feudal system/ a peasant or worker receives a piece land in return for serving the land lord, because of this the society has negative attitude towards the taxpaying culture. From this we can generalize that there is hardly any culture which enhances the voluntary compliance of tax payer's in the country Ethiopia. Lack of voluntary tax compliance was a great problem in Ethiopia and it hindering the revenue collection of the country as well in other similar emerging countries. Because of this, the country has facing budgetary deficit for a long period of time. Ethiopia has tried a lot to change the existing tax administration system and introduced modern tax administration system very recently. There are several amendments was made which encourages voluntary compliance and discourages non voluntary compliance. The tax administration system was mainly concerned with the legal measurement taken as the only means to ensure the tax payer's compliance with taxation. The tax proclamation number 286/2002 deals with the legal action taken on those tax payers who are not compliant and the penalties and sanctions that should be imposed on them before that, nothing else has discussed about the creation of awareness of tax payers. Even if there is tax payer's education in the proclamation but it was provided occasionally as well deals with the contents of tax laws rather than creating awareness about paying tax is one's responsibility as a citizen. Again its main concern was building on institutional capacity and placement of the laws and rules regarding tax noncompliance rather there is hardly any effort has made to create awareness for tax payers' about the benefit of paying taxes for the development of the country and the means to incentivize those who are compliant.

In Ethiopia, the government collects and imposes taxes from two sources, these are direct and indirect taxes. Direct taxes are taxes including employment income tax, rental income tax, business profit income tax, agricultural income tax, and taxes on royalties and chance winnings, while indirect taxes are mainly composed of value added tax (VAT), excise tax, custom duty and turn over tax. Ethiopia has undertaken so many measures to reform the tax administration system, but Littlie has done to enhance the voluntary compliance of tax payer's over the last many decades. For example, the share of direct taxes has declined from about $40 \%$ in the period $1979-80$ to $1991-92$ to about 34\% during 1992-93 to $2007-$ 08 and continue to decline (Abay, 2010).

Furthermore, the tax-to-GDP ratio (11\%) is lower than the average for developed countries tax systems (25-35\%), developing countries (18-25\%) and even of the Sub-Saharan average tax system (16\%) (Abay, 2010). According to Yesgat, 2009, it's impossible to compare the tax to GDP ratios of various countries because there is difference in the definition of the tax base, the awareness and attitude level of the tax payer's and overall condition it is difficult to conclude the indicative and practice.
Regarding Ethiopia, the tax revenue performance of Ethiopia is very low when compared to other sub Saharan countries.

The existence of high-level noncompliance assumed to be caused by the application of excessive enforcement mechanisms and ignoring the behavioral aspects of tax compliance decision making issues of income taxpayers such as tax fairness is described as the main reason for the low level of tax income, especially the business income tax, (Belay, 2016). According to this proclamation, the tax authorities have the power of selling the properties of tax non complaints without the prior permission from the court to collect the unpaid taxes from the evaders.

From the above scenario one can confidently conclude that depending only on legal measurement and building the institutional capacity to ensure the voluntary compliance might not practical ever and at all times. Therefore, it is a must for tax authorities to be fair and follow all inclusive and participating method rather than stick approach to ensure the tax payer's voluntary compliance. Voluntary compliance of tax payer's was the back bone of the workable, efficient and effective taxation system. In Ethiopia, like other developing countries, only limited studies performed on tax fairness perception, especially on business profit taxpayers' (Tessema, 2015, Samuel Alemnew Belay and P. Viswanadham, 2016). Hence, Taxpayers' perception towards fairness of tax system is one of the factors that enable the government to achieve its goals and programs. Besides, it reduces the country's dependability on the foreign loan and donations.

\section{OBJECTIVES OF THE STUDY}

- To evaluate the effect of electronic taxing system in creating tax payer's insight about the equity of tax administration system.

- To examine the effect of adopting e-taxing in creating the insights of the tax payers about the justice of tax administration.

- To evaluate the factors affecting tax payer's insight towards justice and equity of the tax administration system.

- To provide basic information and support for the authority to collect tax revenue effectively by using etaxation system.

\section{RESEARCH METHODOLOGY}

A descriptive research design was used to conduct the study. Research approach can be considered as a blue print, a master plan that specifies the methods (Leedy\&Ormrod, 2013). So, every research requires a research design that is carefully examined to the exact needs of the problem under investigation (Greener, 2008). To attain the objective of the research the researcher had conducted Descriptive analysis \& legit model approaches. These models have employed both qualitative and quantitative approaches to collect, analyze and interpret data.

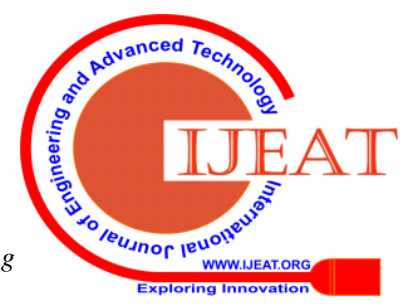


When applying them in combination, qualitative and quantitative methods complement each other and facilitate complete analysis (Creswell, 2009).

The advantage of this method is to help examine in-depth; gather information from limited samples than from all the questionnaires and in addition conduct surveys on taxpayers and this was used for this study.

\section{Target Population}

The target population in this study are Category "B" business income taxpayers' in Wolaita Sodo town of Merkato and Mehal sub city. Wolaita Sodo town is divided into 3 sub cities namely; Merkato, Mehal and Areda. Merkato and Mehal sub city are the target area of the study. According to STTRA (2018) total category B business income taxpayers' data obtained from Wolaita Sodo town Revenue and Custom authorities, there are 370 registered Category B business profit tax payers' in Merkato and Mehal sub city.

\section{Sampling Technique and Sampling Procedure}

Out of the total 370, category B tax payers in two sub cities, it was decided to use 134 samples by using the Yemane formula. The formula is used to calculate the sample size with a 95\% confidence level and with 0.05 errors (Yamane, 1967: 886).

$\mathrm{n}=\underline{\mathrm{Nn}}=370 / 1.925=192$

$1+\overline{\mathrm{N}}(\mathrm{e}) 2$

Where, $\mathrm{n}=$ Sample size

$\mathrm{N}=$ Population size

e = level of precision, i.e. 0.05

After the sample size determined, stratified random sampling was used. This technique was chosen because the sampling frame could be categorized into relatively homogeneous groups (strata) in their business type. The stratum designed based on their type of sectors includes; such as trader (wholesaler and retailers), manufacturers and service providers After stratification, random sampling technique from the probability methods was used to draw the final sampling units which was made to be proportional to the total number of business in each stratum.

\section{Type and Sources of data}

The study has used both qualitative and quantitative data.

\section{Model Specification}

The objective of the study is to evaluate the effect of electronic taxing system in creating tax payer's insight about the equity of tax administration system, the case of Wolaita Sodo town tax revenue authority in Ethiopia. Thus, the model assumes binary outcome, whether the business income tax system is fair/or not. To measure the tax payer's insights about the effects of electronic tax system, the logistic regression model is found appropriate. This is because the logistic regression model is written in terms of the odds ratio and log of odds ratio to interpret the coefficients (Gujarati, 2004). In this study, the odds ratio is the ratio of the probability that the insight towards tax system was fair $\left(\mathrm{P}_{\mathrm{i}}\right)$ to the probability that the tax system was not fair $\left(1-\mathrm{P}_{\mathrm{i}}\right)$.

\section{RESULT AND DISCUSSION}

Table1. Descriptive statistics on the effect of e-tax on the insight towards tax system

\begin{tabular}{|c|c|c|c|c|c|c|c|c|c|c|c|c|}
\hline \multirow{2}{*}{$\begin{array}{l}\text { Dimension of insight of tax payer's towards } \\
\text { the tax administration system }\end{array}$} & \multicolumn{2}{|c|}{ SD } & \multicolumn{2}{|c|}{$\mathbf{D}$} & \multicolumn{2}{|c|}{$\mathrm{N}$} & \multicolumn{2}{|c|}{ A } & \multicolumn{2}{|c|}{ SA } & \multirow{3}{*}{$\begin{array}{c}\mathrm{M} \\
\text { ea } \\
\mathrm{n} \\
\\
3.3 \\
5\end{array}$} & \multirow{3}{*}{$\begin{array}{c}\text { St. } \\
\text { dev. }\end{array}$} \\
\hline & $\begin{array}{l}\mathrm{N} \\
\mathbf{0}\end{array}$ & $\%$ & No & $\%$ & No & $\%$ & No & $\%$ & No & $\%$ & & \\
\hline Sum of tax complexity & 8 & 4.2 & 47 & 24.5 & 24 & $\begin{array}{c}12 . \\
5\end{array}$ & 95 & 49.5 & 18 & 9.4 & & \\
\hline $\begin{array}{l}\text { The term used in the tax return forms are difficult } \\
\text { to understand }\end{array}$ & 2 & 1 & 12 & 6.2 & 7 & 3.6 & 20 & 10.4 & 7 & 3.6 & $\begin{array}{c}0.9 \\
7\end{array}$ & 1.1 \\
\hline $\begin{array}{l}\text { The tax system is transparent \& understandable to } \\
\text { tax payers. }\end{array}$ & 3 & 1.5 & 18 & 9.3 & 5 & 2.6 & 27 & 14 & 5 & 2.6 & $\begin{array}{c}0.8 \\
7\end{array}$ & 1.11 \\
\hline $\begin{array}{c}\text { Tax proclamation change \& difficult to get } \\
\text { guidebooks and other similar explanatory } \\
\text { material }\end{array}$ & 1 & 0.5 & 9 & 4.7 & 4 & 2 & 14 & 7.3 & 2 & 1 & 0.8 & 0.76 \\
\hline $\begin{array}{l}\text { Tax office managers \& others have necessary } \\
\text { information available to take decisions available } \\
\text { to take decisions }\end{array}$ & 2 & 1 & 8 & 4.2 & 8 & 4.2 & 34 & 17.7 & 4 & 2 & $\begin{array}{c}0.7 \\
1\end{array}$ & 0.86 \\
\hline Sum of General knowledge & 15 & 7.8 & 43 & 22.4 & 29 & $\begin{array}{c}15 . \\
1\end{array}$ & 102 & 53.1 & 3 & 1.6 & $\begin{array}{c}3.1 \\
8\end{array}$ & 1.05 \\
\hline $\begin{array}{l}\text { I have little idea about the deductions that I can } \\
\text { claim as a taxpayer in the computation of my tax } \\
\text { liability }\end{array}$ & 2 & 1 & 11 & 5.7 & 7 & 3.6 & 24 & 12.5 & 1 & 0.5 & 0.8 & 0.42 \\
\hline $\begin{array}{l}\text { I understand the explanation \& proclamation of } \\
\text { tax and revenue authority guidebooks \& other } \\
\text { materials }\end{array}$ & 3 & 1.5 & 14 & 7.3 & 6 & 3.1 & 22 & 11.4 & 1 & 0.5 & $\begin{array}{c}0.7 \\
8\end{array}$ & 0.66 \\
\hline $\begin{array}{l}\text { I don't have any challenges with completing \& } \\
\text { filing tax return forms }\end{array}$ & 4 & 2.1 & 8 & 4.2 & 8 & 4.2 & 28 & 14.6 & 0 & 0 & $\begin{array}{c}0.6 \\
6\end{array}$ & 1.56 \\
\hline
\end{tabular}


The Effect of Electronic Taxing System in Creating Taxpayers Insight about the Equity and Justice of Tax System

\begin{tabular}{|c|c|c|c|c|c|c|c|c|c|c|c|c|}
\hline $\begin{array}{l}\text { The form used in the tax declaration form } \\
\text { difficult to understand }\end{array}$ & 6 & 3.1 & 10 & 0.5 & 8 & 4.2 & 28 & 14.6 & 1 & 0.5 & $\begin{array}{c}0.9 \\
4 \\
\end{array}$ & 0.11 \\
\hline Sum of General Insight & 4 & 2.1 & 72 & 37.5 & 27 & $\begin{array}{c}14 . \\
1\end{array}$ & 82 & 42.7 & 7 & 3.6 & $\begin{array}{c}3.0 \\
8\end{array}$ & 1.01 \\
\hline Tax evasion is ethical if the tax system is unfair & 1 & 0.5 & 22 & 11.4 & 8 & 4.2 & 24 & 12.5 & 3 & 1.5 & $\begin{array}{c}1.1 \\
2\end{array}$ & 0.99 \\
\hline $\begin{array}{l}\text { I believe that I pay my fair share of the tax } \\
\text { burden under the current income tax system. }\end{array}$ & 1 & 0.5 & 28 & 14.5 & 12 & 6.2 & 30 & 15.6 & 1 & 0.5 & $\begin{array}{c}0.6 \\
4\end{array}$ & 1.54 \\
\hline $\begin{array}{c}\text { As far as I know the business profit tax is not fair } \\
\text { in general }\end{array}$ & 2 & 1 & 22 & 11.4 & 7 & 3.6 & 28 & 14.6 & 3 & 1.5 & $\begin{array}{c}1.3 \\
2 \\
\end{array}$ & 0.46 \\
\hline Sum of exchange justice and equity & 6 & 3.1 & 23 & 12 & 29 & $\begin{array}{c}15 . \\
1\end{array}$ & 115 & 59.9 & 19 & 9.9 & $\begin{array}{c}3.6 \\
1\end{array}$ & 0.93 \\
\hline $\begin{array}{l}\text { I receive fair value from the government in return } \\
\text { for my income tax paid }\end{array}$ & 2 & 1 & 9 & 4.7 & 18 & 9.4 & 47 & 24.4 & 8 & 4.2 & $\begin{array}{c}1.7 \\
6\end{array}$ & 1 \\
\hline $\begin{array}{c}\text { The income taxes that I have to pay are high } \\
\text { considering the benefits received from the } \\
\text { government }\end{array}$ & 4 & 2.1 & 14 & 7.3 & 11 & 5.7 & 68 & 35.4 & 11 & 5.7 & $\begin{array}{c}1.8 \\
5\end{array}$ & 1.34 \\
\hline Sum Horizontal justice and equity & 13 & 6.8 & 42 & 21.9 & 55 & $\begin{array}{c}28 . \\
6\end{array}$ & 76 & 39.6 & 6 & 3.1 & 3.1 & 1 \\
\hline $\begin{array}{l}\text { I believe it is fair for me to pay a similar share of } \\
\text { income tax compared with other taxpayers } \\
\text { earning an equivalent amount of income }\end{array}$ & 6 & 3.1 & 14 & 7.3 & 23 & $\begin{array}{c}11 . \\
9\end{array}$ & 30 & 15.6 & 3 & 1.6 & 1.2 & 0.9 \\
\hline $\begin{array}{l}\text { It is fair for individuals with similar amounts of } \\
\text { income to pay a similar amount of income tax. }\end{array}$ & 3 & 1.6 & 18 & 14.6 & 18 & 9.3 & 32 & 16.7 & 2 & 1 & 0.9 & 0.88 \\
\hline $\begin{array}{l}\text { everyone who earns similar amount income } \\
\text { sourced in this country is taxable }\end{array}$ & 4 & 2.1 & 10 & 5.2 & 14 & 7.2 & 14 & 7.3 & 1 & 0.5 & 1 & 1.12 \\
\hline Sum of Vertical justice and equity & 15 & 7.8 & 95 & 49.5 & 35 & $\begin{array}{c}18 . \\
2\end{array}$ & 43 & 22.4 & 4 & 2.1 & $\begin{array}{c}2.6 \\
1\end{array}$ & 0.98 \\
\hline $\begin{array}{l}\text { It is fair that high-income earners are subject to } \\
\text { tax at progressively higher tax rates than low- } \\
\text { income earners. }\end{array}$ & 7 & 3.6 & 36 & 18.8 & 8 & 4.2 & 22 & 11.4 & 2 & 1 & 1.1 & 0.87 \\
\hline $\begin{array}{l}\text { It is fair that low-income earners are taxed at a } \\
\text { lower rate than middle-income earners. }\end{array}$ & 5 & 2.6 & 24 & 12.5 & 12 & 6.2 & 18 & 9.3 & 1 & 0.5 & $\begin{array}{c}0.8 \\
2\end{array}$ & 0.67 \\
\hline $\begin{array}{l}\text { It is fair that low-income earners receive more } \\
\text { benefits from the government compared to high } \\
\text { income earner }\end{array}$ & 3 & 1.6 & 35 & 18.2 & 15 & 7.8 & 13 & 6.8 & 1 & 0.5 & $\begin{array}{c}0.6 \\
9\end{array}$ & 0.76 \\
\hline Sum Retributive justice and equity & 6 & 3.1 & 30 & 15.6 & 11 & 5.7 & 100 & 52.1 & 45 & 23.4 & $\begin{array}{c}3.7 \\
7\end{array}$ & 1.07 \\
\hline $\begin{array}{l}\text { I believe that I do not have to be abide by the } \\
\text { deadline for the submission of tax return form }\end{array}$ & 3 & 1.6 & 19 & 9.9 & 4 & 2.1 & 42 & 21.8 & 23 & 11.9 & $\begin{array}{c}1.9 \\
3\end{array}$ & 0.85 \\
\hline $\begin{array}{c}\text { The rules related to income tax are not clear and } \\
\text { understandable that cause penalized }\end{array}$ & 3 & 1.6 & 11 & 5.7 & 7 & 3.6 & 58 & 30.2 & 22 & 11.5 & $\begin{array}{c}1.8 \\
4\end{array}$ & 1.01 \\
\hline Sum of Administrative justice and equity & 4 & 2.1 & 16 & 8.3 & 21 & $\begin{array}{c}10 . \\
9\end{array}$ & 103 & 53.6 & 48 & 25 & $\begin{array}{c}3.9 \\
1\end{array}$ & 0.93 \\
\hline $\begin{array}{l}\text { Administration of income tax system by taxing } \\
\text { Authority is consistent across years and taxpayers }\end{array}$ & 2 & 1 & 7 & 3.6 & 12 & 6.2 & 49 & 25.5 & 27 & 14 & $\begin{array}{c}1.9 \\
7\end{array}$ & 0.9 \\
\hline
\end{tabular}

\section{The Logistic Regression Model Results}

$\mathrm{SD}=$ Strongly disagree, $\mathrm{D}=$ Disagree, $\mathrm{N}=$ Neutral, $\mathrm{A}=$ Agree, $\mathrm{SA}=$ Strongly agree

Source: Business taxpayers survey and own computation

As shown from table 4.13, descriptive statistics on sum of fairness perception $37.5 \%$ and $49.5 \%$ of respondents disagree with general fairness and vertical fairness. Besides sum of tax complexity, sum of general knowledge and sum of horizontal fairness were $24.5 \%, 22.4 \%$ and $21.9 \%$ disagree respectively. Almost half and above respondents' sum of perceptions dimensions were agreed on fairness of taxation. $7.8 \%$ of the respondents strongly disagree with sum of general knowledge and sum of vertical fairness. Majority of respondents agreed on sum of exchange fairness. Overall perception of tax payers assessed as they perceive differently on using likert-scale using questions for each dimension.
Under this section, the logistic regression model results of Wald's test, mean value, p-value, R-square and adjusted Rsquare, significant test, path coefficients were discussed from SPSS outputs. To test the effect of electronic taxing system on tax payer's perception about the justice and fairness of the taxation system in Wolaita Sodo town in Ethiopia, the mean values of justice and fairness and twotailed p-value is used to evaluate the whether or not perception is different or not. All dimension of fairness, tax system complexity with exception to horizontal fairness is shown on the p-value column shown for values less than 0.05 . The tax payer's perception towards the fairness of business profit tax payer's the Wald's test is used.

Published By:

Blue Eyes Intelligence Engineering \& Sciences Publication 
According to the Wald's test result, all tax payers' has different insights about the fairness and justice of the tax administration system. And also the result shows that, tax payer's have less perception of fairness and tax knowledge. Regarding the complexity of the tax system, the Wald's test result shown that, the tax administration system is more complex. The predictive association among the variables is presented by the path coefficients in logistic regression model. According to the path coefficients for justice and fairness dimension, with exception to horizontal justice and equity, other variables like tax knowledge and tax complexity were highly significant at 0.05 levels. Finally, the $\mathrm{R}$ square value suggests to what extent the independent constructs help to explain the dependent constructs, thus the bigger the $\mathrm{R}$ square result, the more predicted power the model possess.

Therefore, the R square shows that $70 \%$ of those fairness dimension tax knowledge and tax complexity system explain the dependent variable.

Table 4.2. 1 Summary of the Regressions Model/using logit model

\begin{tabular}{|c|c|c|c|c|c|c|c|}
\hline Variables & $\mathbf{R}^{2}$ & Adjusted $\mathbf{R}^{2}$ & $\begin{array}{c}\text { Path } \\
\text { coefficient }\end{array}$ & $\begin{array}{c}\text { Wald's } \\
\text { statistics }\end{array}$ & $\begin{array}{l}\text { Significa } \\
\text { nce level }\end{array}$ & Mean & $\begin{array}{c}\text { P- } \\
\text { value(two } \\
\text { tailed) }\end{array}$ \\
\hline $\begin{array}{l}\text { Effect of electronic taxing on } \\
\text { tax payer's insight towards } \\
\text { the tax administration system }\end{array}$ & 0.58 & 0.62 & & & & & \\
\hline Tax Complexity & & & 0.041 & 2.85 & 0.05 & 3.35 & .00 \\
\hline Tax knowledge & & & 0.023 & 3.12 & 0.05 & 3.18 & .01 \\
\hline General justice and equity & & & 0.028 & 3.45 & 0.05 & 3.08 & .62 \\
\hline Exchange justice and equity & & & 0.012 & 4.21 & 0.05 & 3.61 & .00 \\
\hline Horizontal justice and equity & & & 0.016 & 3.88 & 0.05 & 3.10 & .00 \\
\hline Vertical justice and equity & & & 0.031 & 3.73 & 0.05 & 2.61 & .00 \\
\hline $\begin{array}{c}\text { Retributive justice and } \\
\text { equity }\end{array}$ & & & 0.412 & 5.24 & 0.05 & 3.77 & .01 \\
\hline $\begin{array}{c}\text { Administrative justice and } \\
\text { equity }\end{array}$ & & & 0.367 & 3.68 & 0.05 & 3.91 & .004 \\
\hline
\end{tabular}

Level of significance; $p<0.001,{ }^{*} p<0.005$, Tol=Tolerance level(acceptable level $<0,10$ )

Source: Business taxpayers survey and own computation administration system as a dependent construct and the independent construct in the study the correlation test is conducted.

Table 4.22 correlation between the tax payer's insight towards the tax administration system and eight constructs.

\section{Pearson correlation coefficient}

To test the relationship between effect of electronic taxing on tax in enhancing the tax payer's insight towards the tax

Table 4.2. 2 Correlation of major Variables

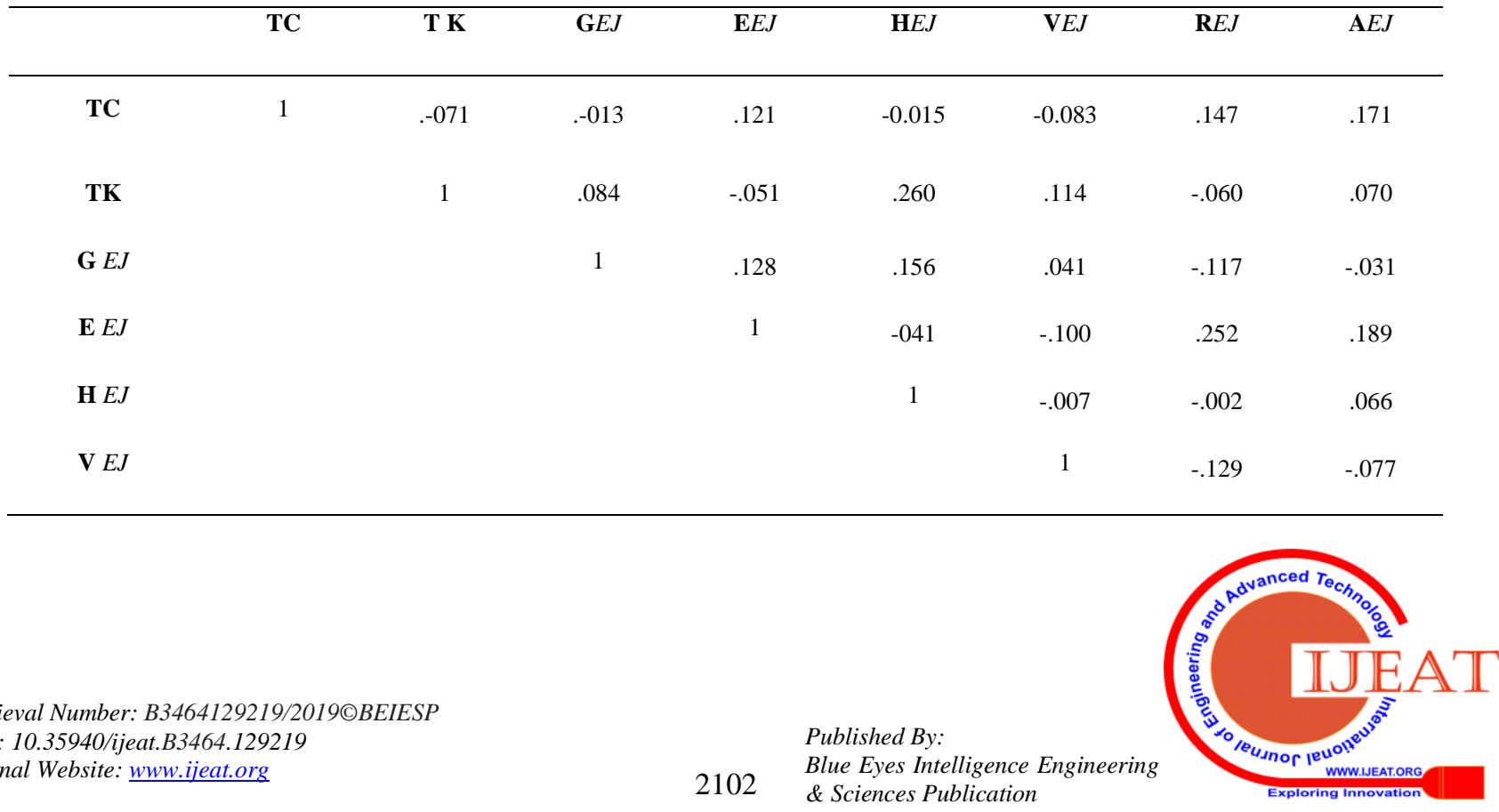


Correlation is significant at the 0.05 level (2-tailed).

Note that:TC( tax complexity),TK(tax knowledge), GEJ(gen eral equity and justice), EEJ

(exchange equity and justice), HEJ (horizontal equity and justice),VEJ ( vertical equity and justice), REJ (Retributive equity and justice),ADEJ (administrative equity and justice) Source: Business profit taxpayers survey and own computati on

\section{CONCLUSION}

The result from this study provides the effects of electronic taxing system in enhancing the insights about the fairness perception of tax administration system in Category ' $B$ ' tax payers in Wolaita Sodo town, SNNPR of Ethiopia. The survey result was presented from three different aspects of fairness. These are economic, political and social aspects. The logistic regression analysis showed, out of eight variables (tax fairness aspects) in the model; 8 tax fairness aspects namely; tax complexity, tax general knowledge, tax general fairness, exchange fairness, horizontal fairness, vertical fairness, redistributive fairness, administrative fairness have significant effects on tax fairness in the current tax system but General fairness is insignificant at 5\% level of CI.

Based on the finding of the study the following recommendations were given:-

The tax authority should teach at least semiannually the tax payers about the payment of tax obligation and the kind of tax evasion in context of their day to day business operation. 1. The revenue authority should create suitable environment for tax payers through training the tax officers to be more approachable and friendly in helping tax payers, providing clear information about the tax payments, organizing free public tax meeting and forum to create awareness for tax payers to prevent tax evasion.

2. The revenue authority should also employ skilled and qualified auditors as well as licensed professional accountant to prevent tax evasion. tax evaders based on the rules and regulations as per articles 960 of the income tax proclamation number 286/2002 mainly in monetary value and

4. The revenue authority should improve the attitude of the business taxpayers towards the importance of taxation and its effect on the economy development

5. To change the negative perceptions towards the taxation system, it's better to apply an individual's actual income based.

6. The tax authorities should provide sufficient tax training to improve the awareness of tax payer's towards taxation system.

7. More efforts would be exerted in providing tax information through various means at local and federal level about the rights and duties of tax payer's to bring the growth in the economy of the country in general and well being of its citizens in particular.
3. The government should also apply the punishment for

\section{REFERENCES}

1. Abubakari Abdul - Razak and C. J. Adafula (2013). "Evaluating taxpayers ${ }^{\text {ee }}$ attitude and its influence on tax compliance decisions in Tamale, Ghana." Journal of Accounting and Taxation 5(3): 48-57.

2. Adams, J. S. (1965). Inequity in social exchange.In L.Berkowitz (Ed.), Advances in Experimental Psychology (pp. 267-299). New York: Academic Press.

3. Anna A. CheAzmi and Kamala A. Perumal (2008). "Tax fairness dimensions in an Asian context: The Malaysian perspective." International Review of Business Research Papers 4(5): 11-19.

4. Ahmed, A. and S. Kedir (2015). "Tax compliance and its determinant the case of Jimma zone, Ethiopia." International Journal of Research in Social Science 6(2): 7-21.

5. Alm, J. and B. Torgler (2011). "Do Ethics Matter? Tax Compliance and Morality." Journal of Business Ethics 101(4): 635-651.

6. Berhe R. and Sekhon S. (2016). "Taxpayerse Knowledge and Tax Compliance Behavior in Ethiopia: A Study of Tigray State." International Journal of Management and Commerce Innovations 3(2): 1090-1102.

7. Chau, G. and Leung, P. (2009). A critical review of Fischer tax compliance model: A research synthesis. Journal of Accounting and taxation 1(2): 034-040.

8. Council of Ministers (2002).Income Tax Proclamation No 286/2002.NegaritGazetta, FDRE

9. Das-Gupta, A., and Chattopadhyay, S. (2002). The Personal Income Tax in India: Compliance Costs and Compliance Behavior of Taxpayers. National Institute of Public Finance and Policy, New Delhi.

10. Fischer CM, Wartick M, Mark M (1992). Detection Probability and Taxpayer Compliance: A Review of the Literature. Journal of Accounting Literature 11(2): 1-46. Fowler, F J 1984, Survey research methods, SAGA publications, California.

11. Fuller, L. (1961). The adversary system. In H. Berman (Ed.), Talks on American Law (pp. 10-22). New York: Vintage Books.

12. GeletawTsegawTessema (2015). Taxpayers ${ }^{\text {ee }}$ tax compliance Behavior- Business profit taxpayers ${ }^{\text {ee }}$ of Addis Ababa city Administration. Master's thesis, Addis Ababa University, Department of Accounting and Finance.Retrieved December 26, 2018, from https://www.scribd.com/document/326037217/Taxpayers-taxcompliance-Behavior-Business-profit-taxpayers-of-Addis-Ababacity-Administration.

13. Jackson\&Milliron B. R., C. V. (1986). Tax compliance research: Findings, problems and prospects. Journal of Accounting Literature, 5, $125-165$.

14. Kazemi, A. (2008). There is more to fairness in taxation than fair taxes: Introducing a multi-faceted fairness framework of taxation. Dynamics Within and Outside the Lab. The 6th Nordic Conference on Group and Social Physchology (GRSP), Lund, Lund university.

15. Lamm, H., \& Schwinger, T. (1980). Norms concerning distributive justice: Are needs taken into consideration in allocation decisions? Social Psychology Quarterly, 43(4), 425-429

16. Leventhal, G. S., Karuza, J., \& Fry, W. R. (1980).Beyond fairness: A theory of allocation preferences. In G. Mikula (Ed.), Justice and Social Interaction (pp. 167-218). New York: Springer-Verlag.

17. Synodinos, N.(2003). The 'art' of questionnaire construction: Some important considerations for manufacturing studies. Integrated Manufacturing Systems, 14(3), 221-237.

18. McKerchar, M (2001). „Why do taxpayers comply? Past lessons and future directions in developing a model of compliance behaviour ${ }^{\text {ee }}$ Australian Tax Forum, 16: 99-134.

19. Mukasa, J. (2011). Tax knowledge, perceived tax fairness and tax compliance in Uganda.The case of small and medium income taxpayers in Kampala central division.Master's thesis, Makerere University, Department of Accounting and Finance. Retrieved December

26,2018,http://www.academia.edu/5619390/Tax_knowledge_perceive d_tax_fairness_and_tax_compliance_in_Uganda. 
20. Saad, N. (2010). Fairness perceptions and compliance behaviour: The case of salaried taxpayers in Malaysia after implementation of the self-assessment system. eJournal of Tax Research 8(1): 32-63.

21. Samuel Alemnew Belay and P. Viswanadham (2016). "Tax Fairness Perceptions and Compliance Behavior: Evidence from the Metropolitan Cities of the Amhara Regional State of Ethiopia." International Journal of Science and Research 5(4): 1173-1183.

22. Schwinger, T. (1980). Just allocation of goods: Decisions among three principles. In G. Mikula (Ed.), Justice and Social Interaction (pp. 95-125). New York: Springer-Verlag. SerkanBenk, Tamer Budak and AhmetFerdaCakmak (2012). "Tax professionals"e perceptions of tax fairness: Survey evidence in Turkey." International Journal of Business and Social Science 3(2): 112-117.

23. TaddeseLenchoGemechu (2014). The Ethiopian income tax system: Policy, design and practice. PhD dissertation, University of Alabama, Department of Interdisciplinary Studies, Tuscaloosa, Alabama

24. TemtimeDebere (2014). Business Taxpayerse Satisfaction with the Tax System in Addis Ababa, Ethiopia.Master's thesis, Addis Ababa University, Department of Accounting and Finance.Retrieved December 26, 2018 from http://etd.aau.edu.et/bitstream/123456789/5104/1/Temtime\%20Deber e.pdf.

25. TigistMamoFufa( 2017)Taxpayers' perception towards: Tax fairness, tax knowledge and tax complexity of Bole sub city category "B" business profit taxpayers.

26. Thibaut, J. W., \& Walker, L. (1975). Procedural Justice: A Psychological Analysis. Hillsdale: Lawrence Erlbaum.

27. TsegabirhanWeldegiorigisAbay, (2010). Domestic Resource Mobilization in Sub - Saharan Africa: The case of Ethiopia. AAU.

28. Tulu, L. (2007). Determinants of Taxpayers ${ }^{\text {ee }}$ Voluntary Compliance with Taxation: The Case Study of Dire Dawa City. Master's thesis, Addis Ababa University, Department of Management Wenzel, M (2003). Tax compliance and the psychology of justice: mapping the field, In Taxing Democracy: Understanding Tax Avoidance and Evasion, edited by Valerie Braithwaite, 41-69. United Kingdom: Ashgate Publishing Ltd.

29. Wenzel, M. (2007)."The Multiplicity of Taxpayer Identities and Their Implications for Tax Ethics." Law \& Policy 29(1): 31-50.

30. WollelaAbehodieYesegat and Odd-HelgeFjeldstad (2016). Business people ${ }^{e c}$ views of paying taxes in Ethiopia. ICTD Working Paper 43, Institute of Development Studies.

31. WubshetAborat G/Meskel (2011). Taxpayers' perceptions towards fairness: Personal business profit taxpayers in Addis Ababa. Master's thesis, Addis Ababa University, Department of Accounting and Finance.

32. WaleshetYesegat, (2009): Value Added Tax in Ethiopia: A Study of Operating Costs and Compliance, $\mathrm{PhD}$ Thesis submitted to the Faculty of Law of the University of New South Wales.

\section{AUTHORS PROFILE}

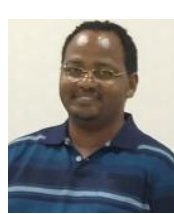

Mesele Kebede Manaye , (Assistant professor, in the department of accounting and finance, Wolaita Sodo university, Ethiopia and has done his BA degree in Finance from Adama University, Ethiopia and Msc in Accounting from Ambo University, Ethiopia. Now he is a $\mathrm{PhD}$ research scholar in accounting and finance in the school of Management, KIIT, Bhubaneswar.

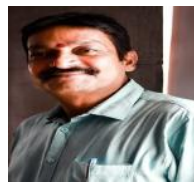

Professor Dr. B.C.M.Patnaik, M.Com, Ph.D., KIIT school of Management, KIIT, Bhubaneswar, Odisha. More than 20 years of rich experience in Educational Research, Content and Creative initiative. Published 34 papers in Scopus indexed journals.

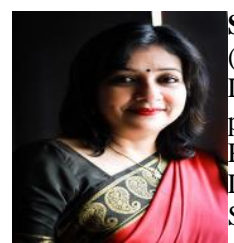

Senior Professor Dr. Ipseeta Satpathy, MA, M.Phil (JNU, New Delhi), Ph.D , D.Litt., visiting professor to Lynchburg College, Virginia, USA, awardee of the prestigious Oxford Journal Distinguished Research Professor Award 2014 held at Cambridge University, London. The author has published 45 research papers in Scopus indexed journals. 